\title{
SOIL CHEMICAL ATTRIBUTES AND CORN PRODUCTIVITY GROWN ON LEGUME STUBBLE IN AGROFORESTRY SYSTEMS ${ }^{1}$
}

\author{
LEONARDO SANTOS COLLIER ${ }^{2}$, EVERTON MARTINS ARRUDA ${ }^{3 *}$, LUIZ FERNANDES CARDOSO CAMPOS ${ }^{2}$, \\ JOSÉ NILTON VIEIRA NUNES ${ }^{4}$
}

\begin{abstract}
Leguminous species can improve nutrient cycling and chemical quality of Oxisols, resulting in higher productivity of intercropped crops. Thus, this research aimed to evaluate the decomposition rate and nutrient accumulation in legume stubble, as well as its contribution to soil chemical attributes, the growth of baru trees (Dipteryx alata Vogel), and yield of intercropped maize in an agroforestry system. The experiment was developed during the crop years of 2010-2011 and 2011-2012, in Goiás State, Brazil. The experimental design was a randomized block with five replicates. Leguminous species consisted of sunn hemp (Crotalaria juncea), jack bean (Canavalia ensiformis), pigeon pea (Cajanus cajan), Stylosanthes (Stylosanthes macrocephala - 20\% and Stylosanthes capitata - 80\%), and spontaneous vegetation (control treatment). The decomposition rates of legume and spontaneous vegetation residues remained unchanged in the agroforestry system. Sunn hemp, jack bean, and Stylosanthes plants are advantageous options for total accumulation of nutrients. However, sunn hemp grown as straw cover for next crop seasons increases the available phosphorus levels in the soil and productivity of maize cobs. With this coverage, maize productivity values were up to $24 \%$ higher than were those with maize growing on spontaneous vegetation, besides having no effect on the growth of baru trees.
\end{abstract}

Keywords: Sunn hemp. Cover crop plants. Consortium systems. Phosphorus.

\section{ATRIBUTOS QUÍMICOS DO SOLO E PRODUTIVIDADE DE MILHO EM RESIDUAL DE LEGUMINOSAS EM SISTEMA AGROFLORESTAL}

RESUMO - O uso de espécies leguminosas poderá favorecer a ciclagem de nutrientes e a qualidade química dos latossolos, o que de certa forma promoverá maior desempenho dos cultivos consorciados. Desta forma, objetivou-se com esta pesquisa avaliar a taxa de decomposição e o acúmulo de nutrientes em leguminosas, além dos atributos químicos do solo, crescimento de barueiros e produtividade de milho cultivados em rotação no sistema agroflorestal. A pesquisa foi realizada em consórcio com árvores de barueiros (Dipteryx alata Vogel), durante o período das safras 2010-2011 e 2011-2012, no estado de Goiás, Brasil, O delineamento experimental foi em blocos casualizados, com cinco repetições. As leguminosas utilizadas foram: crotalária (Crotalaria juncea); feijão de porco (Canavalia ensiformis); feijão guandu (Cajanus cajan); estilosantes campo grande (Stylosanthes macrocephala - $20 \%$ e Stylosanthes capitata - $80 \%$ ) e vegetação espontânea (tratamento controle). A taxa de decomposição dos resíduos de leguminosas e vegetação espontânea não é afetada no sistema agroflorestal. A crotalária, o feijão de porco e o estilosantes apresentam-se como opções vantajosas para o acúmulo total de nutrientes. Porém, o cultivo de crotalária com manejo de palhada visando rotação para próxima safra aumenta os teores de fósforo disponível no solo e a produtividade de espigas de milho verde com valores até $24 \%$ superiores em relação à área mantida sob vegetação espontânea, além de não afetar o crescimento das árvores.

Palavras-chave: Crotalária. Plantas de cobertura. Sistemas consorciados. Fósforo. 


\section{INTRODUCTION}

Baru (Dipteryx alata Vogel) is a forest native tree from Brazilian cerrado and produces chestnuts and wood, being a tree option for agroforestry systems. The inclusion of agricultural areas in agroforestry consortia is a sustainable alternative for small farmers, especially when maize (Zea mays) is used as a source of annual financial income through the trade of its green ears. Maize farming in Brazil presents a great socioeconomic highlight due to its use in several agroindustrial complexes (ALBUQUERQUE et al., 2013). However, maize is a C4 plant with high grain yield and biomass requiring an intensive fertilization since it exports significant amounts of nutrients (PRADO, 2008). In addition to this demand, the association of maize with tree species in intercropping systems suggests a higher intake of nutrients from the soil, which increases the dependence of mineral fertilizers (ABREU et al., 2016).

To reduce this dependence, it is important to use cover crops before the growing of annual crops to promote an efficient use of available nutrients (COLLIER et al., 2008; COLLIER et al., 2011; BARROS; GOMIDE; CARVALHO, 2013), improved soil protection (DAMOUR; GUÉRIN; DOREL, 2016), and benefits to soil chemical attributes (CANELLAS et al., 2004; PEREZ; SMYTH; ISRAEL, 2007). Additionally, there is an increase in mineralization and availability of nutrients to the plants (TORRES; PEREIRA; FABIAN, 2008; PACHECO et al., 2017), mainly by biological fixation of nitrogen (BARROS; GOMIDE; CARVALHO, 2013), and release of cations and phosphate anions to soil solution (PAVINATO; ROSOLEM, 2008).

In Cerrado biome, cover crop qualitative characteristics associated with soil and climate conditions may alter decomposition rates, changing the soil nutrient availability dynamics (TORRES; PEREIRA, 2008; PACHECO et al., 2017), determining the time crop residues should remain on the soil surface for a faster decomposition (TORRES et al., 2014). Most of the studied and grown leguminous used as mulch in Brazilian cerrado are Crotalaria juncea (sunn hemp) (TORRES et al., 2014), Canavalia ensiformis (jack bean) (COLLIER et al., 2011), Stylosanthes (stylosanthes) (PEREZ; SMYTH; ISRAEL, 2007), and Cajanus cajan (pigeon peas) (ROSA et al., 2011).

Maize grown in succession to legume species has shown high yields (CARVALHO et al., 2004; BARROS; GOMIDE; CARVALHO, 2013). Legumes can meet the needs of sustainable crop systems and positively influence maize productivity
(ALBUQUERQUE et al., 2013) for being an important source of nitrogen to the system, replacing mineral fertilization and recycling nutrients (TORRES; PEREIRA; FABIAN, 2008).

In this study, we started off with the belief that the management of legumes as cover crops would favour the cycling of nutrients and the chemical quality of the soil, improving the performance of the intercropped crops. Thus, the objective of this research was to evaluate the decomposition rate and accumulation of nutrients in leguminous cover crops, as well as soil chemical attributes, baru trees growth, and yield of maize grown after a cover crop in an agroforestry system.

\section{MATERIAL AND METHODS}

The study was carried out in the city of Goiânia, state of Goiás, Brazil. The area is located between the coordinates of $16^{\circ} 36^{\prime} 11^{\prime \prime}$ South and $49^{\circ}$ 16' 47" West. The local climate is classified as an Aw type (Megathermal), i.e. tropical of savannahs, with dry winters and rainy summers, according to the classification of Köppen. The study area lies at an altitude of $728 \mathrm{~m}$, presenting an average annual rainfall of $1600 \mathrm{~mm}$ and minimum and maximum annual temperatures of 15.2 and $30.4^{\circ} \mathrm{C}$, respectively (Figure 1 ).

The soil is characterized as a typical dystrophic Red Latosol (Typic Haplorthox), according to the Brazilian System of Soil Classification - SIBCS (EMBRAPA, 2013), or Oxisol according to the US Soil Taxonomy (USDA). A soil chemical analysis prior to experiment obtained the following values: $\mathrm{Ca}: 1.24 \mathrm{cmol}_{\mathrm{c}} \mathrm{dm}^{-3}$, $\mathrm{Mg}^{2+}: \quad 0.81 \mathrm{cmol}_{\mathrm{c}} \mathrm{dm}^{-3}, \quad \mathrm{~K}^{+}: \quad 89.7 \mathrm{mg} \mathrm{dm}^{-3}$,

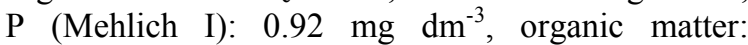
$13.5 \mathrm{~g} \mathrm{dm}^{-3}, \quad \mathrm{Al}^{3+}: \quad 0.2 \quad \mathrm{cmol}_{\mathrm{c}} \mathrm{dm}^{-3}, \mathrm{H}+\mathrm{Al}$ : $5.01 \mathrm{cmol}_{\mathrm{c}} \mathrm{dm}^{-3}$ and $\mathrm{pH}\left(\mathrm{CaCl}_{2}\right): 4.9$, cation exchange capacity: $7.29 \mathrm{cmol}_{\mathrm{c}} \mathrm{dm}^{-3}, \mathrm{~V} \%: 31.3 \%$. All the soil chemical attributes were determined according to EMBRAPA (2009). Soil texture presented a clay content of $432 \mathrm{~g} \mathrm{~kg}^{-1}$ soil in the 0-0.2 m layer (EMBRAPA, 1997).

The experimental area had been grown with Brachiaria decumbens grass, as main vegetation, until 2006, when baru tree (Dipteryx alata Vogel) seedlings $(0.4 \mathrm{~m}$ height $)$ were planted in planting holes $(0.4 \times 0.4 \times 0.4 \mathrm{~m})$. This area contained six rows with 12 trees each one, spaced in $3.0 \mathrm{~m}$ between trees and $6.0 \mathrm{~m}$ between rows, totalling 72 trees. Trees received no fertilization, remaining fallow for four years (2006 to 2010), in 2010, leguminous were sown. 


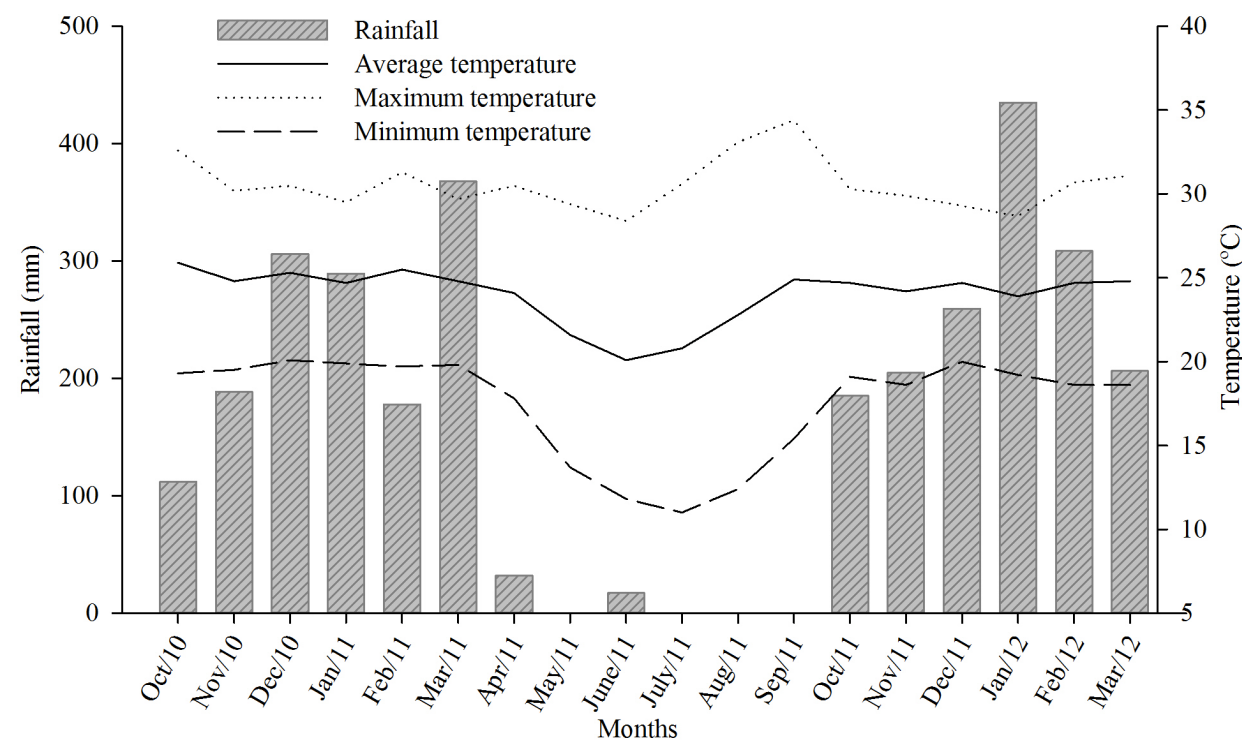

Figure 1. Rainfall, average maximum and minimum monthly temperatures during the experiment, Goiânia-GO (Brazil), 2010-2012.

In September 2010, the soil underwent conventional tillage by heavy and light harrowing. Then, legumes were sowed between rows, beside baru trees, containing two trees per experimental plot. The leguminous cover crops were: sunn hemp (Crotalaria juncea); jack beans (Canavalia ensiformis); pigeon peas (Cajanus cajan); stylosanthes (Stylosanthes macrocephala - 20\% and Stylosanthes capitata - 80\%) and spontaneous vegetation (as a control treatment) with Brachiaria decumbens dominance, Ipomoea quamoclit, Bidens pilosa and Cyperus rotundus. Each plot was $5 \mathrm{~m}$ wide and $6 \mathrm{~m}$ long $\left(30 \mathrm{~m}^{2}\right)$ and disregarded $1.0 \mathrm{~m}$ at the extremities, having a useful area of $20 \mathrm{~m}^{2}$ in the centre. The total experimental area was of $750 \mathrm{~m}^{2}$. The experimental design was a randomized block with five replicates.

Manual seeding was performed in October 2010 , without any organic or mineral fertilization. The spacing was $0.45 \mathrm{~m}$ between leguminous rows, and sowing densities were $4 \mathrm{~kg} \mathrm{ha}^{-1}$ for stylosanthes, and 35,5 , and 20 seeds per meter for pigeon peas, jack beans, and sunn hemp, respectively.

In January 2011, cover crop shoots were harvested for the first time (above $0.25 \mathrm{~m}$ ), after 80 days of sowing (at flowering). Later, 170 days after sowing, another harvest was carried out (April 2011). In November 2011, cover plants were dried with glyphosate $\left(2.0 \mathrm{~L} \mathrm{ha}^{-1}\right)$, prior to maize sowing. The sowing of maize (cultivar Zenit 2353) was made in $0.9-\mathrm{m}$ spaced rows, placing five seeds per meter, with a final stand of 55 thousand plants per hectare. Base fertilization consisted of $60 \mathrm{~kg} \mathrm{ha}^{-1} \mathrm{P}_{2} \mathrm{O}_{5}$, using triple superphosphate. After 25 days, a topdressing of $25 \mathrm{~kg} \mathrm{ha}^{-1} \mathrm{~N}$ and $30 \mathrm{~kg} \mathrm{ha}^{-1} \mathrm{~K}_{2} \mathrm{O}$, using ammonium sulphate and potassium chloride respectively, by broadcasting. These doses are lower than those recommended for monocrops (SOUSA; LOBATO, 2004), with the purpose of checking a potential residual effect of leguminous residues on maize and baru plants.

In both leguminous harvests, we used a metal frame quadrat $(0.5 \times 0.5 \mathrm{~m})$. The harvested plant shoot samples were dried in an oven at $60{ }^{\circ} \mathrm{C}$ until a constant weight, for dry matter measurements $\left(\mathrm{Mg} \mathrm{ha}^{-1}\right)$. After weighing, dry matter samples were taken to chemical analysis for $\mathrm{N}, \mathrm{P}, \mathrm{K}, \mathrm{Ca}$, and $\mathrm{Mg}$ in plant tissue, following the method proposed by Malavolta, Vitti and Oliveira (1997). By plant biomass and nutrient contents in plant shoot, we could calculate the total nutrient accumulation, in $\mathrm{kg} \mathrm{ha}^{-1}$ (PRADO, 2008). Soon after harvesting, the evaluated biomass samples returned to the experimental plots, being redistributed evenly over the soil. Nearly $50 \%$ of this material was placed under the projection of canopy of baru trees. The other $50 \%$ remained between the lines. Such distribution was adopted to favouring both baru trees and maize crop.

To evaluate the decomposition of legume biomass, litter bags were used (THOMAS; ASAKAWA, 1993). These bags were made of nylon with a mesh size of $0.002 \mathrm{~m}$ and had an internal area of $0.05 \mathrm{~m}^{2}(0.20 \times 0.25 \mathrm{~m})$. Inside each bag was placed an aliquot of $100 \mathrm{~g}$ fresh plant material. Thereafter, four of these bags were distributed randomly on the soil surface of each plot. Evaluations were made for both legume harvests, with sampling at 20,40, and 60 days after bag scattering, being then oven dried at $65{ }^{\circ} \mathrm{C}$ until reaching a constant mass, for dry mass measurements.

Decomposition dynamics parameters were calculated based on the remnant residual mass after 
60 days of decomposition. The exponential mathematical model used to describe plant residue decomposition was the following (Equation 1).

$$
X=X 0 e^{-K \times t}
$$

Where: $\mathrm{X}$ is the amount of dry mass or nutrient remaining, after a period of time $t$, in days; $\mathrm{X} 0$ is the initial amount of dry mass or nutrient; $\mathrm{k}$ is the decomposition constant (THOMAS; ASAKAWA, 1993). By rearranging the terms of the equation, it is possible to calculate the decomposition and nutrient release constant $(\mathrm{k})$ for the material (Equation 2).

$$
k=-\ln \left(\frac{(x / x 0)}{t}\right)
$$

With the value of $\mathrm{k}$, the half-life (Equation 3) was calculated, which expresses the time required for half of the residues to decompose or for half of the nutrients contained in the residues to be released (PAUL; CLARK, 1989).

$$
\mathrm{T} 1 / 2=\frac{(2)}{k}
$$

Soil sampling was performed at depth range between $0-0.2 \mathrm{~m}$, together with the harvesting of green maize cobs. Four simple soil samples were taken from each experimental unit to form a composite sample. Soil sampling was done in the inter-rows, under the canopy projection of trees (SOUSA; LOBATO, 2004). The following soil chemical attributes were determined: $\mathrm{Ca}$ and $\mathrm{Mg}$ (extracted in $\mathrm{KCl}$ ), potential acidity $(\mathrm{H}+\mathrm{Al})$, $\mathrm{pH}$ $\left(\mathrm{CaCl}_{2}\right)$, and contents of phosphorus and potassium (extracted in Mehlich I), both according to EMBRAPA (1997). By these data, we could calculate base sum (BS), cation exchange capacity (CEC), and base saturation (V\%). Soil organic matter contents were determined by dichromate oxidation method with spectrophotometer reading (EMBRAPA, 2009).

The harvesting of green maize cobs was carried out in January 2012. The green cobs were sampled two meters far from the three central rows of each plot. Subsequently, the green ears with straw were weighed for average yield $\left(\mathrm{Mg} \mathrm{ha}^{-1}\right)$. Yet baru tree growth was evaluated in 2010 (before legume sowing) and in 2012 (after maize harvest). It was assessed by measuring plant height $(\mathrm{m})$ and $\mathrm{DBH}$ (mean diameter at breast height, at $1.3 \mathrm{~m}$ from the soil level), using a hypsometer and a dendrometric calliper, respectively. Afterwards, growth increment both in height and DBH were calculated by subtracting the values observed in 2012 from those of 2010 , these data were transformed to percentage of growth (\%).

The statistical analyses consisted of analysis of variance (F-test) and, when significant, means were compared by the tukey test $(\mathrm{p}<0.05$ or 0.01$)$ using SISVAR software (Statistical Analysis, version 5.6) (FERREIRA, 2011). Yet for straw decomposition rate, we used an exponential equation adjustment with graphs plotted by Sigma Plot software, version 12.0 .

\section{RESULTS AND DISCUSSION}

Among the evaluated cover crops, sunn hemp showed a higher dry mass (DM) production in the first harvesting, being similar to stylosanthes (Figure 2). Sunn hemp DM production was 66\% higher than that of jack beans and spontaneous vegetation, and $81 \%$ higher than that of pigeon peas. Nonetheless, in the second harvest, DM production was similar among all leguminous cover crops.

The high sunn hemp DM production in the first harvest was probably due to its pivotal root system, which penetrates deeper into the soil, increasing the soil volume explored for water and nutrients (TORRES et al., 2014). In general, sunn hemp DM production varies from 3.5 to $5.3 \mathrm{Mg} \mathrm{ha}^{-1}$ (CARVALHO et al., 2004); here, it reached up to 8.1 $\mathrm{Mg} \mathrm{ha}^{-1}$ (SILVA et al., 2010). In this research, the total DM production of both sunn hemp and stylosanthes were considered adequate for a conservationist system, based on crop rotation, showing straw amounts superior to $6.0 \mathrm{Mg} \mathrm{ha}^{-1}$ (ALVARENGA et al., 2001). On the other hand, some studies performed in Cerrado biome have considered these crop straw contents low, which leads to an insufficient carbon input into the soil, so higher crop straw DM should be produced, from 11.7 to $13.3 \mathrm{Mg} \mathrm{ha}^{-1}$ (SÁ et al., 2015). 


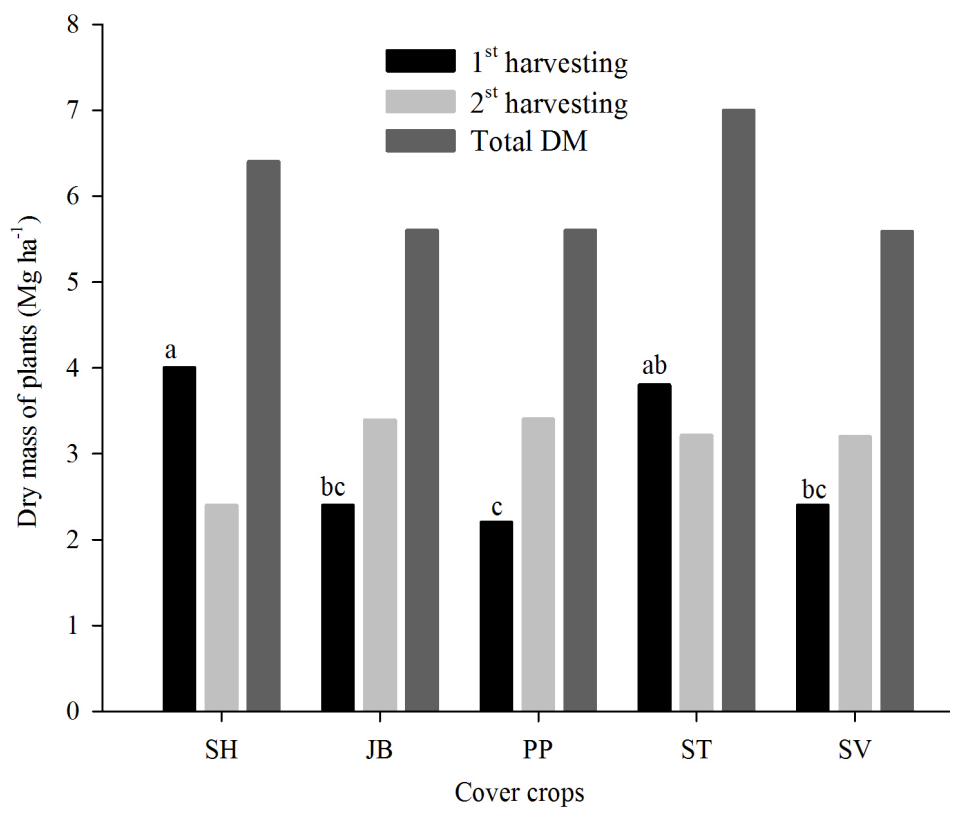

Figure 2. DM production $\left(\mathrm{Mg} \mathrm{ha}^{-1}\right)$ of cover crops in an agroforestry system. Sunn hemp (SH), jack beans (JB), pigeon peas (PP), stylosanthes (ST), and spontaneous vegetation (SV). $1^{\text {st }}$ harvesting DM $\left(\mathrm{F}=6.08^{* *} ; \mathrm{CV}=26.4\right), 2^{\text {nd }}$ harvesting $\mathrm{DM}$ $\left(\mathrm{F}=1.47^{\text {n.s. }} ; \mathrm{CV}=24.5\right)$, total $\mathrm{DM}\left(\mathrm{F}=1.32^{\text {n.s. }} ; \mathrm{CV}=20.5\right)$.

The low DM production by jack beans might have been due to its slower initial growth compared to the other legumes, besides its small size (BARROS; GOMIDE; CARVALHO, 2013). For pigeon peas, low production rates might have derived from its slow growth and bushy habit (DAMOUR; GUÉRIN; DOREL, 2016). In addition, this great reduction in DM production of both legumes could have been caused by the agroforestry system influence, dismissing them for cohabitation with forest species, where there is high competition for sunlight, water, and nutrients.

When compared to spontaneous vegetation, the total amounts of nitrogen $(\mathrm{N})$ accumulated in plant shoots were about 60 and 58\% higher in sunn hemp and stylosanthes, respectively (Table 1). This outcome can be explained by the great ability of nitrogen biological fixation of these species (COLLIER et al., 2008). For sunn hemp, nearly $57 \%$ of the total absorbed $\mathrm{N}$ comes from biological fixation (PERIN et al., 2004), what may also help to save great amounts of nitrogen fertilization in tropical agroecosystems (BARROS; GOMIDE; CARVALHO, 2013).

Despite having $80 \%$ more $\mathrm{P}$ in shoot than SP, the $P$ total accumulation in sunn hemp plants had no difference from the other legumes (Table 1). This leguminous species can contribute economically to agriculture once phosphate fertilizers represent the majority of the costs with fertility amendments for crops in tropical soils (COLLIER et al., 2008).

Total potassium accumulated $\left(\mathrm{K}^{+}\right)$were higher in sunn hemp $\left(95.7 \mathrm{~kg} \mathrm{ha}^{-1}\right)$ and jack beans $\left(97.8 \mathrm{~kg} \mathrm{ha}^{-1}\right)$ residues. The largest accumulations of calcium $\left(\mathrm{Ca}^{2+}\right)$ occurred in jack beans $\left(139.1 \mathrm{~kg} \mathrm{ha}^{-1}\right)$ and stylosanthes $\left(133.7 \mathrm{~kg} \mathrm{ha}^{-1}\right)$ residues.

Likewise, other studies performed in Cerrado have reported high amounts of total $\mathrm{K}^{+}$ (up to $141.1 \mathrm{~kg} \mathrm{ha}^{-1}$ ) in jack beans residues (COLLIER et al., 2008). Conversely, some authors have found lower levels of total $\mathrm{K}^{+}$accumulated in sunn hemp residues (PERIN et al., 2004) compared to the ones obtained here.

Jack beans are efficient in $\mathrm{Ca}^{2+}$ absorption, working as organic reserves (COLLIER et al., 2011). Similarly, stylosanthes also stand out by a great potential of accumulating and releasing this mineral into cropping systems (PEREZ; SMYTH; ISRAEL, 2007). Such trait is common in leguminous species because of the large cation exchange capacity in their roots, which is grown in clayey soils, increases the adsorption of higher-valence cations $\left(\mathrm{Al}^{+3}>\mathrm{Ca}^{+2}>\mathrm{K}^{+}\right)$(MARSCHNER, 2012).

Pigeon peas presented a low total accumulation of magnesium $\left(\mathrm{Mg}^{2+}\right)$ for all leguminous species, being also similar to spontaneous vegetation (Table 1). Total $\mathrm{Mg}^{2+}$ accumulated were only half the levels accumulated by sunn hemp and one-third those of jack beans and stylosanthes residues.

Both $\mathrm{Mg}^{2+}$ and $\mathrm{N}$ are constituents of chlorophyll molecules (MARSCHNER, 2012), what makes the $\mathrm{N}$ metabolism of legumes demanding higher levels of $\mathrm{Mg}^{2+}$. Therefore, a low accumulation of $\mathrm{Mg}^{2+}$, as seen in pigeon peas, can be a limiting factor. It is noteworthy mention that legumes which accumulate greater amounts of $\mathrm{N}$ in shoots also have a highlighted $\mathrm{Mg}^{2+}$ accumulation. 
L. S. COLLIER et al.

Table 1. Total levels (first harvesting + second harvesting) of nitrogen, phosphorus, potassium, calcium, and magnesium $\left(\mathrm{g} \mathrm{kg}^{-1}\right)$ in the shoot of leguminous species and spontaneous vegetation intercropped with baru trees.

\begin{tabular}{cccccc}
\hline Tratament & Nitrogen & Phosphorus & Poassium & Calcium & Magnesium \\
\hline Sunn hemp & $208.2 \mathrm{a}$ & $26.0 \mathrm{a}$ & $95.7 \mathrm{a}$ & $82.7 \mathrm{~b}$ & $30.8 \mathrm{a}$ \\
Jack bean & $197.1 \mathrm{ab}$ & $19.3 \mathrm{ab}$ & $97.8 \mathrm{a}$ & $139.1 \mathrm{a}$ & $45.7 \mathrm{a}$ \\
Pigeon pea & $187.7 \mathrm{ab}$ & $18.9 \mathrm{ab}$ & $56.3 \mathrm{~b}$ & $38.1 \mathrm{bc}$ & $11.2 \mathrm{~b}$ \\
Stylosanthes & $205.6 \mathrm{a}$ & $19.3 \mathrm{ab}$ & $56.6 \mathrm{~b}$ & $133.7 \mathrm{a}$ & $45.1 \mathrm{a}$ \\
S. vegetation & $129.8 \mathrm{~b}$ & $14.3 \mathrm{~b}$ & $55.4 \mathrm{~b}$ & $32.1 \mathrm{c}$ & $10.6 \mathrm{~b}$ \\
\hline F (test) & $3.56^{*}$ & $5.53^{* *}$ & $4.85^{* *}$ & $19.08^{* *}$ & $18.49^{* *}$ \\
CV (\%) & 20.57 & 20.30 & 31.23 & 30.51 & 31.10 \\
\hline
\end{tabular}

Means followed by different lowercase letters in the column differ statistically from each other according to the tukey test. $*=$ significant $(\mathrm{p}<0.05) . * *=$ significant $(\mathrm{p}<0.01)$.

The DM results for residues remaining from legumes along time were significantly adjusted to a descending exponential function for all five treatments and both harvests (Figures 3 and 4).

After 20, 40, and 60 days of the first harvest, DM remains were $37.9,22.9$, and $10.0 \%$ for sunn hemp; $39.5,22.9$, and $9.6 \%$ for stylosanthes; 40.6 , 18.4 , and $7.8 \%$ for pigeon pea; $40.6,18.9$, and $8.1 \%$ for jack beans; and 35.2; 30.7, and $15.0 \%$ for spontaneous vegetation (Figure 3). Overall, decomposition kinetics was fast-paced for all evaluated species if compared to the second harvest since DM remaining at the end of the evaluation was lower.

The largest residual dry matter was found for spontaneous vegetation, which means it remained longer in the soil (Figure 3). This finding can be attributed to the presence of Poaceae family plants in the spontaneous vegetation composition; these plants usually produce residues with longer permanence since they present a high $\mathrm{C} / \mathrm{N}$ relationship (ROSA et al., 2011).

When analysing the second harvest, DM remains at 20, 40, and 60 days after cutting were $75.7,61.1$, and $41.0 \%$ for sunn hemp; $75.3,62.8$, and $41.3 \%$ for stylosanthes; $75.0,59.0$, and $39.4 \%$ for pigeon peas; $69.2,41.1$, and $28.2 \%$ for jack beans; and $78.8,64.4$, and $47.5 \%$ for spontaneous vegetation (Figure 4).

In general, the decay curves were slightly accentuated and all treatments presented a similar behaviour except for jack beans, which stood out for losing greater mass in decomposition after 60 days. This decomposition kinetics behaviour is attributed to a poor moisture level in the soil responsible for increasing the activity of decomposing microorganisms. This pattern was quite evident in the first harvest (Figure 3) because decomposition coincided with the rainy season in January and February (Figure 1).

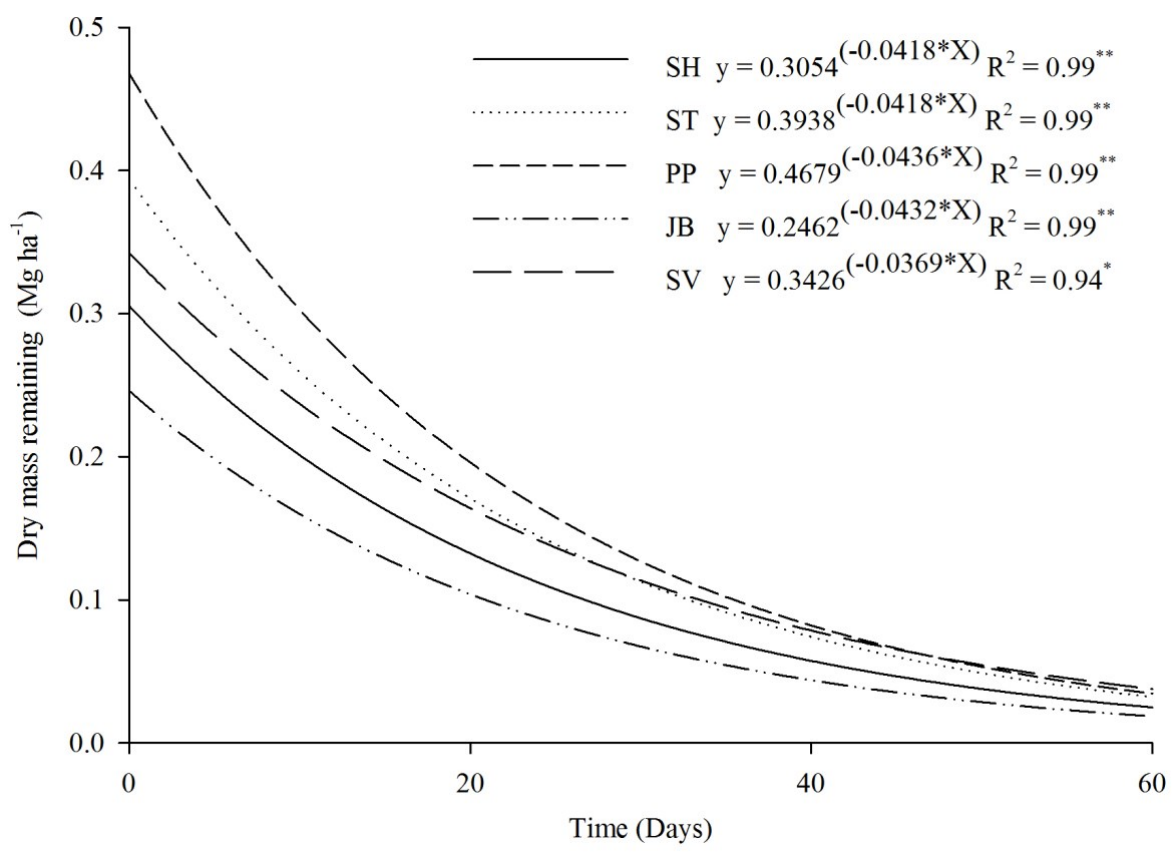

Figure 3. Dry mass remaining of legumes and spontaneous plants as a function of time, after the first harvest. Sunn hemp $(\mathrm{SH})$; jack beans (JB); pigeon peas (PP); stylosanthes (ST) and spontaneous vegetation (SV). ${ }^{*}=$ significant $(\mathrm{p}<0.05)$. $* *=$ significant $(\mathrm{p}<0.01)$. 


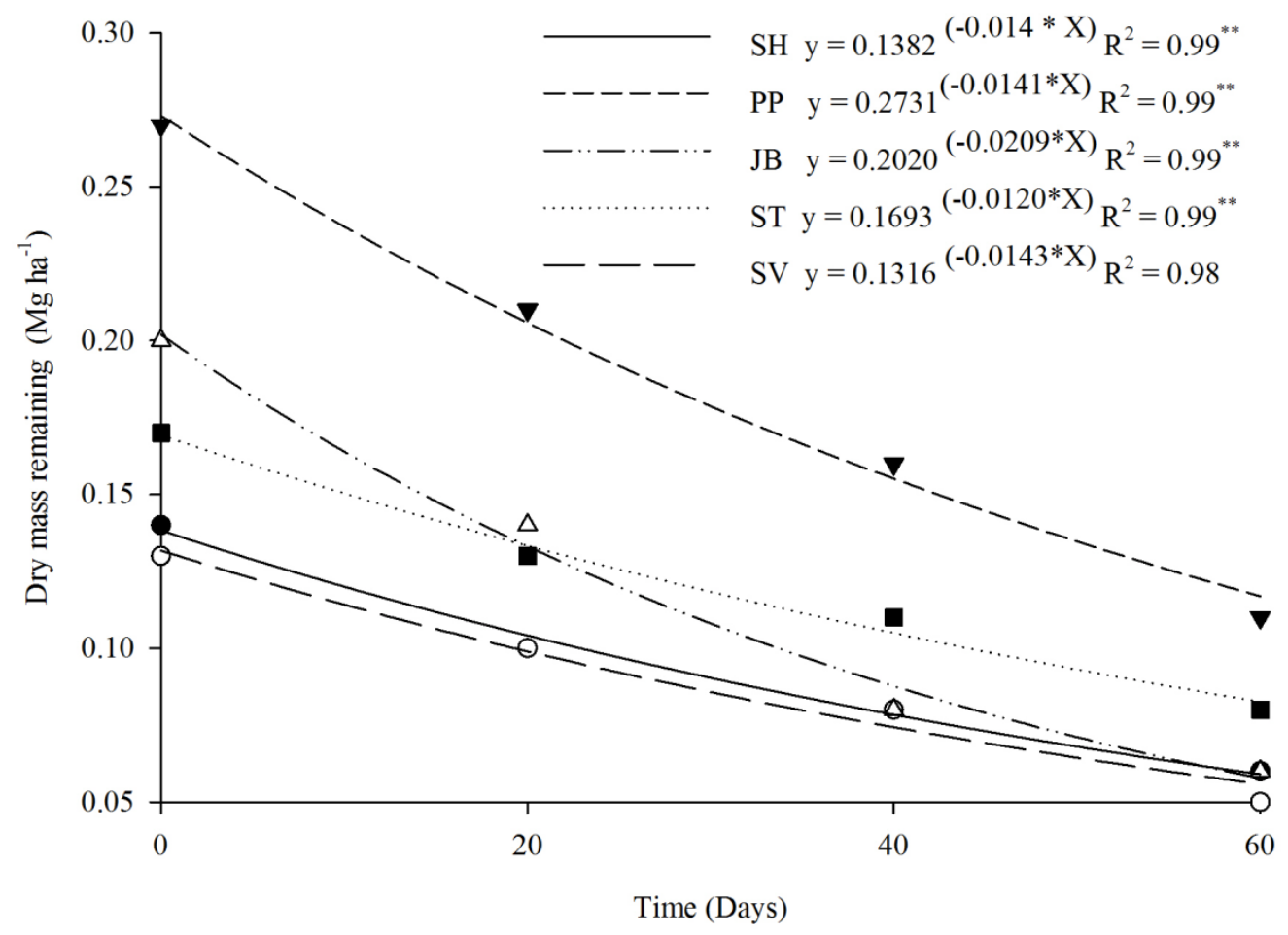

Figure 4. Dry mass remaining of legumes and spontaneous plants as a function of time, after the second harvest. Sunn hemp (SH); jack beans (JB); pigeon peas (PP); stylosanthes (ST) and spontaneous vegetation (SV). *= significant $(\mathrm{p}<0.05) . * *=$ significant $(\mathrm{p}<0.01)$.

For the constant decomposition $(\mathrm{k})$, the results of the analysis of variance confirmed that the largest mass loss was attained by jack beans in the second harvest. Despite that, sunn hemp and stylosanthes presented the greatest constant decomposition in the second harvest (Table 2).

By analysing the parameters of decomposition in both harvests, the effect of climatic conditions becomes evident since high temperatures and high humidity (Figure 1) might have contributed to an increasing microbial activity in the soil. Besides that, there were small lignin and cellulose concentrations in vegetal tissues at harvest time (PACHECO et al., 2017), which, consequently, increased decomposition rate in the first harvest. Thus, the harvesting time may influence legume decomposition rates; periods with intense rainfall events and high temperatures have decreased the half-life of Fabaceae plants (MOREIRA et al., 2009).

Table 2. Decomposition parameters: decomposition constant (k), half-life time (T1/2), and percentage of mass loss (\% loss) in leguminous cover crops, in the first and second harvests.

\begin{tabular}{ccccccc}
\hline \multirow{2}{*}{ Tratament } & \multicolumn{3}{c}{ First harvest } & \multicolumn{3}{c}{ Second harvest } \\
\cline { 2 - 6 } & $\mathrm{k}$ & $\mathrm{t}_{1 / 2}$ & $\%$ loss & $\mathrm{K}$ & $\mathrm{t}_{1 / 2}$ & $\%$ loss \\
\hline Sunn hemp & $0.06 \mathrm{bA}$ & $12 \mathrm{aB}$ & $97.1 \mathrm{aA}$ & $0.01 \mathrm{abB}$ & $57 \mathrm{aA}$ & $55.0 \mathrm{bB}$ \\
Jack bean & $0.07 \mathrm{aA}$ & $9 \mathrm{aB}$ & $98.8 \mathrm{aA}$ & $0.02 \mathrm{aB}$ & $35 \mathrm{bA}$ & $70.1 \mathrm{aB}$ \\
Pigeon pea & $0.07 \mathrm{aA}$ & $9 \mathrm{aB}$ & $98.9 \mathrm{aA}$ & $0.01 \mathrm{abB}$ & $54 \mathrm{abA}$ & $56.2 \mathrm{abB}$ \\
Stylosanthes & $0.06 \mathrm{bA}$ & $11 \mathrm{aB}$ & $97.8 \mathrm{~A}$ & $0.01 \mathrm{abB}$ & $50 \mathrm{abA}$ & $57.6 \mathrm{abB}$ \\
S. vegetation & $0.07 \mathrm{aA}$ & $10 \mathrm{aB}$ & $98.7 \mathrm{aA}$ & $0.01 \mathrm{bB}$ & $60 \mathrm{aA}$ & $51.5 \mathrm{bB}$ \\
\hline F (test) & $8.75^{* *}$ & $146.53^{* *}$ & $328.70^{* *}$ & $8.75^{* *}$ & $146.53^{* *}$ & $328.70^{* *}$ \\
CV (\%) & 5.06 & 3.78 & 0.24 & 31.06 & 33.13 & 19.08 \\
\hline
\end{tabular}

Means followed by different lowercase letters in the column and uppercase in the line differ statistically from each other according to the tukey test. ${ }^{*}=$ significant $(\mathrm{p}<0.05)$. ${ }^{* *}=$ significant $(\mathrm{p}<0.01)$. 
The levels of available $P$ in the soil increased when growing sunn hemp. It demonstrates that this species of legumes was more efficient in recycling this nutrient in soil surface layers (Table 3). These results might have occurred due to the organic acids released by sunn hemp, which interacts with the soil solid phase occupying adsorption sites of anionic nutrients (PAVINATO; ROSOLEM, 2008). Another possibility would be the formation of diester phosphate bonds, increasing the proportion between P-diester and P-monoester in soil surface layer (CANELLAS et al., 2004), facilitating the formation of more P-labile forms (PAVINATO; ROSOLEM, 2008).

The levels of available $\mathrm{P}$ in the soil under sunn hemp residues were fairly high, being 78, 100, 142 , and $78 \%$ higher compared to jack beans, pigeon peas, stylosanthes, and spontaneous vegetation, respectively. Such rises in available $\mathrm{P}$ levels are important towards a continuous agroforestry system in the next agricultural year, where this residual $\mathrm{P}$ in the soil represents a relevant reduction in the costs of phosphate fertilization.

Table 3. Chemical attributes of soil under an agroforestry system with baru trees and maize grown on leguminous and spontaneous vegetation residues, at a depth range of $0.0-0.2 \mathrm{~m}$.

\begin{tabular}{ccccccccccc}
\hline & $\mathrm{P}$ & $\mathrm{K}$ & $\mathrm{Ca}$ & $\mathrm{Mg}$ & $\mathrm{OM}$ & $\mathrm{pH}$ & $\mathrm{H}+\mathrm{Al}$ & $\mathrm{BS}$ & $\mathrm{CEC}$ & $\begin{array}{c}\mathrm{V} \\
\%\end{array}$ \\
\hline Sunn hemp & $6.8 \mathrm{a}$ & 54.0 & 1.0 & 0.40 & 2.20 & 5.10 & 5.20 & 1.60 & 6.67 & 23.96 \\
Jack bean & $3.8 \mathrm{~b}$ & 54.2 & 1.1 & 0.60 & 2.00 & 5.00 & 5.40 & 2.05 & 7.42 & 27.57 \\
Pigeon pea & $3.4 \mathrm{~b}$ & 46.2 & 1.4 & 0.80 & 1.80 & 5.60 & 4.80 & 2.21 & 6.86 & 32.19 \\
Stylosanthes & $2.8 \mathrm{~b}$ & 50.0 & 1.2 & 0.80 & 2.40 & 5.40 & 5.00 & 1.81 & 6.88 & 26.12 \\
S.vegetation & $3.8 \mathrm{~b}$ & 46.8 & 1.2 & 1.00 & 2.20 & 5.40 & 4.60 & 1.87 & 6.62 & 28.65 \\
\hline F (test) & $15.3^{*}$ & $1.5^{\text {n.S. }}$ & $1.2^{\text {n.s. }}$ & $1.3^{\text {n.s. }}$ & $1.4^{\text {n.s. }}$ & $2.2^{\text {n.s. }}$ & $1.3^{\text {n.s. }}$ & $1.9^{\text {n.s. }}$ & $1.1^{\text {n.s. }}$ & $1.9^{\text {n.s. }}$ \\
CV $(\%)$ & 21.50 & 13.49 & 29.2 & 59.7 & 20.29 & 7.58 & 12.25 & 19.43 & 9.69 & 17.75 \\
\hline
\end{tabular}

Means followed by different lowercase in the column differ statistically from each other according to the tukey test. $*=$ significant $(\mathrm{p}<0.05) . * *=$ significant $(\mathrm{p}<0.01)$. OM: Organic Matter; BS: base sum; CEC: cation exchange capacity; $\mathrm{V}$ : base saturation.

Although no differences were observed for green maize cob yields among the evaluated legumes, the growing on sunn hemp straw increased in $24 \%$ the productivity if compared to the growing on spontaneous vegetation (Figure 5). Studies in the literature have shown that maize productivity grown on sunn hemp residues is between $18 \%$
(CARVALHO et al., 2004) and 51\% higher compared to crops grown on spontaneous vegetation stubble (SANTOS et al., 2010). In addition, other studies have verified greater productivity levels for maize on sunn hemp residues compared to jack beans (COLLIER et al., 2006) and pigeon peas (ALBUQUERQUE et al., 2013).

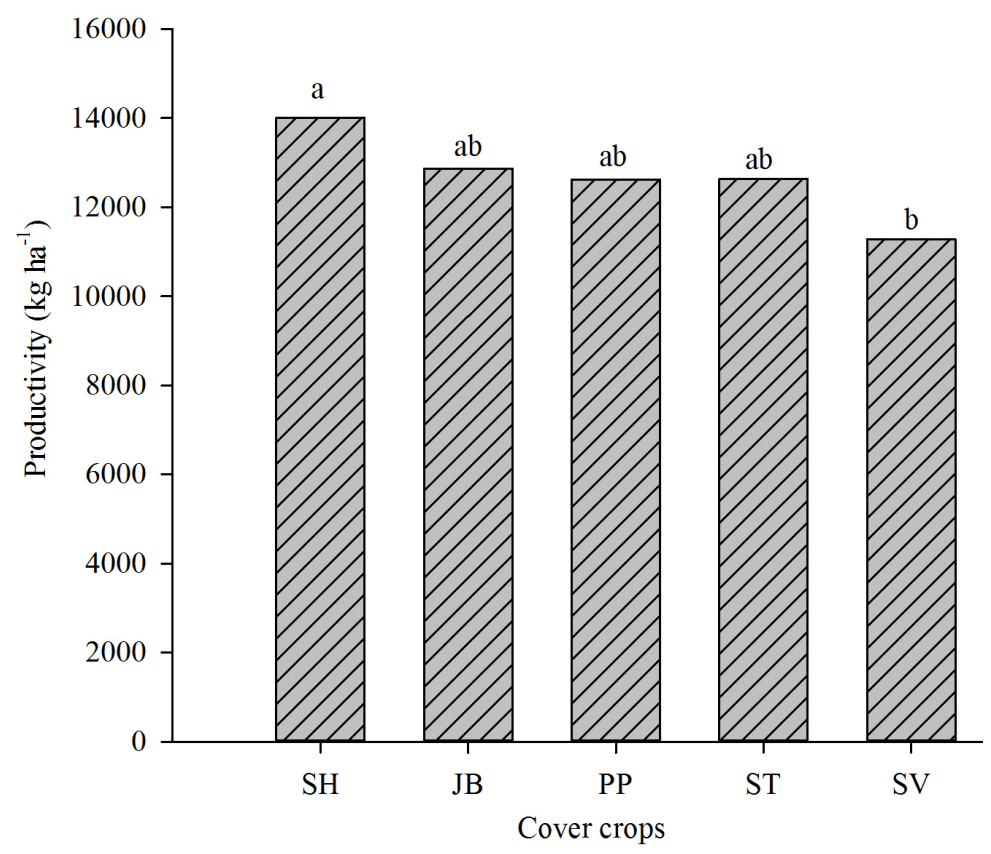

Figure 5. Productivity of green maize cobs in intercropping with baru trees, grown on leguminous cover crops residues: sunn hemp (SH); jack beans (JB); pigeon peas (PP); stylosanthes (ST) e spontaneous vegetation $(\mathrm{SV}) . \mathrm{F}=4.88^{* *}$; $\mathrm{CV}=7.74 \%$. 
These increases in productivity of green cobs for maize grown on sunn hemp residues might have occurred due to this legume higher productivity of dry matter during the first harvest (Figure 2). With an increased amount of organic material remaining on the soil surface for long periods, positive effects were reached regarding maize productivity grown in rotation in an agroforestry system. According to Barros, Gomide and Carvalho (2013), the increased contribution of organic material by mulch plants has enabled greater yields of green cobs in corn crops lately.

Other factors that may have contributed directly to a higher productivity of green cobs were the largest accumulation of $\mathrm{N}\left(208.2 \mathrm{~kg} \mathrm{ha}^{-1}\right)$ and the increments of available $\mathrm{P}$ in the soil solution by the previous cultivation of sunn hemp. All of these inputs of nutrient by sunn hemp residue has confirmed its benefits in straw formation. A large P cycling capability at surface depths by pivoting roots and release of organic acids are meaningful characteristics of some cover crops. These traits promote the maintenance of larger fractions of available $\mathrm{P}$ in the soil for subsequent crops, resulting in a reduction of $\mathrm{P}$ losses for unavailable compartments.

As observed in Figures $6 \mathrm{~A}$ and $6 \mathrm{C}$, the intercropping had no effect on the growth of baru trees in both height and diameter (DBH), respectively. Increases in height varied from 16.13 to $34.00 \%$ (Figure 6D) and in $\mathrm{DBH}$ from 10.69 to $15.77 \%$ (Figure 6B).
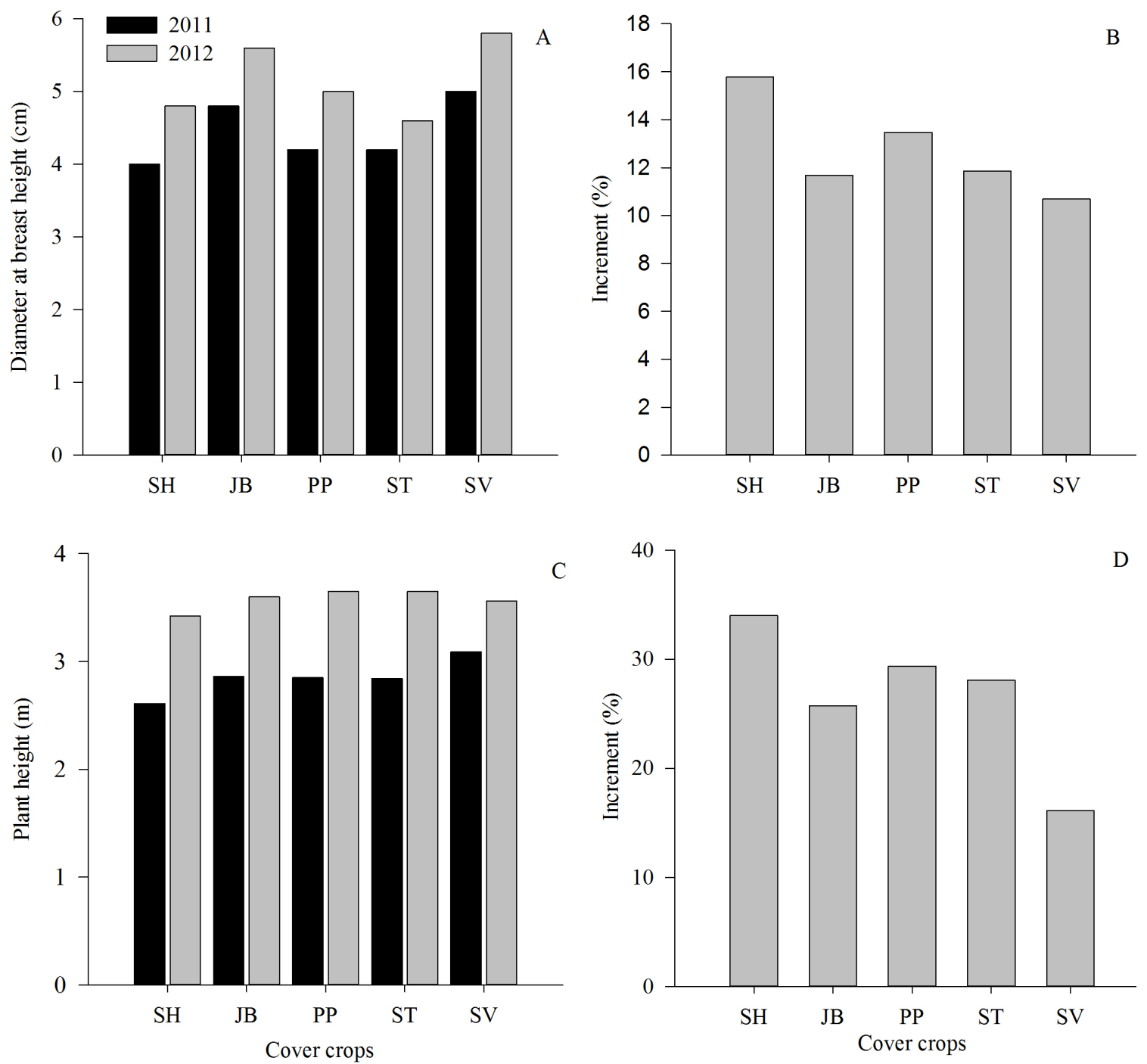

Figure 6. Height (C), diameter (A), and growth increment (B and D) of baru trees intercropped with leguminous and spontaneous vegetation in 2011 and 2012. 
Baru is a Brazilian forest species with great adaptation to acidic and poor fertility soils, as in Cerrado biome. This arboreal plant has a rapid initial growth (VENTUROLI et al., 2013). When evaluations started, these trees were already 4 years old, what might have caused the absence of significant differences $(p>0.05)$ when intercropping with legumes and with spontaneous vegetation. This result shows that regardless of using legume species, the growth of these trees is not affected, being soil cover directly related to the type of adopted management and the subsequent cropping system.

\section{CONCLUSIONS}

The decomposition rates of legume residues and spontaneous vegetation were not affected in the agroforestry system.

Sunn hemp, jack beans, and stylosanthes are advantageous cover species for total nutrient accumulation, being able to reduce fertilization costs.

Among the studied species, an agroforestry system using sunn hemp as straw for subsequent crops may increase the content of available phosphorus in the soil, as well as raise the productivity of maize cobs, being about $24 \%$ higher than those crops on spontaneous vegetation, besides not affecting the growth of baru trees.

\section{REFERENCES}

ABREU, S. A. H. et al. Chemical attributes of the soil in agroforestry systems subjected to organic fertilizations. African Journal of Agricultural Research, Victoria Island Lagos. v. 10, n. 27, p. 2378-2388, 2016.

ALBUQUERQUE, A. W. et al. Plantas de cobertura e adubação nitrogenada na produção de milho em sistema de plantio direto. Revista Brasileira de Engenharia Agrícola e Ambiental, Campina Grande, v. 17, n. 7, p. 721-726, 2013.

ALVARENGA, R. C. et al. Plantas de cobertura de solo para sistema plantio direto. Informe Agropecuário, Belo Horizonte, v. 22, n. 208, p. 2536, 2001.

BARROS, D. L.; GOMIDE, P. H. O.; CARVALHO, G. J. Plantas de cobertura e seus efeitos na cultura em sucessão. Bioscience Journal, Uberlândia, v. 29, n. 2, p. 308-318, 2013.

CANELLAS, L. P. et al. Phosphorus analysis in soil under herbaceous perennial leguminous cover by nuclear magnetic spectroscopy. Pesquisa Agropecuária Brasileira, Brasília, v. 39, n. 6, p.
589-596, 2004.

CARVAlHO, M. A. C. et al. Produtividade do milho em sucessão a adubos verdes no sistema de semeadura direta e convencional. Pesquisa Agropecuária Brasileira, Brasília, v. 39, n. 1, p. 4753. 2004.

COLLIER, L. S. et al. Manejo da adubação nitrogenada para o milho sob palhada de leguminosas em plantio direto em Gurupi, TO. Ciência Rural, Santa Maria, v. 36, n. 4, p. 11001105, 2006.

COLLIER, L. S. et al. Adubação fosfatada no sulco e em faixas sob palhada de leguminosa e produtividade de milho em plantio direto no Tocantins. Revista Ceres, Viçosa, v. 55, n. 2, p. 109 $-116,2008$.

COLLIER, L. S. et al. Consócio e sucessão de milho e feijão-de-porco como alternativa de cultivo sob plantio direto. Pesquisa Agropecuária Tropical, Goiânia, v. 41, n. 3, p. 306-313, 2011.

DAMOUR, G.; GUÉRIN, C.; DOREL, M. Leaf area development strategies of cover plants used in banana plantations identified from a set of plant traits. European Journal of Agronomy, Amsterdam, v. 74, n. 1, p. 103-111, 2016.

EMPRESA BRASILEIRA DE PESQUISA AGROPECUÁRIA - EMBRAPA. Manual de métodos de análises de solos. 2. ed. Brasília, DF: EMBRAPA, 1997. 212 p.

EMPRESA BRASILEIRA DE PESQUISA AGROPECUÁRIA - EMBRAPA. Manual de análises químicas de solos, plantas e fertilizantes. 2. ed. Brasília, DF: EMBRAPA, 2009. 627 p.

EMPRESA BRASILEIRA DE PESQUISA AGROPECUÁRIA - EMBRAPA. Sistema brasileiro de classificação de solos. 3 . ed. Brasília, DF: EMBRAPA, 2013. 353 p.

FERREIRA, D. F. Sisvar: A computer statistical analysis system. Ciência e Agrotecnologia, Lavras, v. 35, n. 6, p. 1039-1042, 2011.

MALAVOLTA, E.; VITTI, G. C.; OLIVEIRA, S. A. Avaliação do estado nutricional das plantas: Princípios e aplicações. 2. ed. Piracicaba, SP: Potafos, 1997. 319 p.

MARSCHNER, H. Mineral nutrition of higher plants. 3. ed. San Diego: Academic Press, 2012. 651 p.

MOREIRA, G. M. et al. Decomposição de feijão-de- 
porco e lab-lab em quatro épocas de corte em cafezal na Zona da Mata de Minas Gerais. Revista Brasileira de Agroecologia, Pelotas, v. 4, n. 2, p. 2734-2737, 2009.

PACHECO, L. P. et al. Biomass and nutrient cycling by cover crops in Brazilian cerrado in the state of Piaui. Revista Caatinga, Mossoró, v. 30, n. 1, p. 1323, 2017.

PAUL, E. A.; CLARK, F. E. Soil microbiology and biochemistry. San Diego: Academic Press, 1989. $275 \mathrm{p}$.

PAVINATO, P. S.; ROSOLEM, C. A. Disponibilidade de nutrientes no solo decomposição e liberação de compostos orgânicos de resíduos vegetais. Revista Brasileira de Ciência do Solo, Viçosa, v. 32, n. 3, p. 911-920, 2008.

PEREZ, M. J.; SMYTH, T. J.; ISRAEL, D. W. Comparative effects of two forage species on rhizosphere acidification and solubilization of phosphate rocks of different reactivity. Journal of Plant Nutrition, Athens, v. 30, n. 9, p. 1421-1439, 2007.

PERIN, A. et al. Produção de fitomassa, acúmulo de nutrientes e fixação biológica de nitrogênio por adubos verdes em cultivo isolado e consorciado. Pesquisa Agropecuária Brasileira, Brasília, v. 39, n. 1, p. 35-40, 2004.

PRADO, R. M. Nutrição de Plantas. 1. ed. Jaboticabal, SP: Editora UNESP, 2008. 407 p.

ROSA, D. M. et al. Desempenho da cultura do milho implantada sobre resíduos culturais de leguminosas de verão em sistema plantio direto. Semina: Ciências Agrárias, Londrina, v. 32, n. 4, p. 1287 1296, 2011.

SÁ, J. C. M. et al. Carbon depletion by plowing and its restoration by no-till cropping systems in oxisols of subtropical and tropical agro-ecoregions in Brazil. Land Degradation and Development, Medford, v. 26, n. 6, p. 531-543, 2015.

SANTOS, P. A. et al. Adubos verdes e adubação nitrogenada em cobertura no cultivo do milho. Revista Brasileira de Milho e Sorgo, Sete Lagoas, v. 9 , n. 2, p. 123-134, 2010

SILVA, A. G. et al. Produção de fitomassa e acúmulo de nutrientes por plantas de cobertura e cultivo da mamona em sucessão no sistema plantio direto. Ciência Rural, Santa Maria, v. 40, n. 10, p. 2092-2098, 2010.
SOUSA, D. M. G.; LOBATO, E. Cerrado: correção do solo e adubação. 1. ed. Planaltina, DF: EMBRAPA, 2004. 416 p.

THOMAS, R. J.; ASAKAWA, N. M. Decomposition of leaf litter from tropical forage grasses and legumes. Soil Biology and Biochemistry, Oxford, v. 25, n. 10, p. 1351-1361, 1993.

TORRES, J. L. R. et al. Cultivo de feijão e milho em sucessão a plantas de cobertura. Revista Caatinga, Mossoró, v. 27, n. 4, p. 117-125, 2014.

TORRES, J. L. R.; PEREIRA, M. G. Dinâmica do potássio nos resíduos vegetais de plantas de cobertura no Cerrado. Revista Brasileira de Ciência do Solo, Viçosa, v. 32, n. 4, p. 1609-1618, 2008.

TORRES, J. L. R.; PEREIRA, M. G.; FABIAN, A. J. Produção de fitomassa por plantas de cobertura e mineralização de seus resíduos em plantio direto. Pesquisa Agropecuária Brasileira, Brasília, v. 43, n. 3, p. 421-428, 2008.

VENTUROLI, F. et al. Incremento de espécies arbóreas em plantio de recuperação de área degradada em solo de cerrado no distrito federal. Bioscience Journal, Uberlândia, v. 29, n. 1, p. 143$151,2013$. 